\section{The Hippocratic oath}

\section{Is alive and well in North America}

EDrToR,-If, as Irvine Loudon speculates, oath taking by medical graduates in the United Kingdom is a myth it stands in stark contrast with the use of medical oaths in Canada and the United States. I have followed the growth of the use of medical oaths in the United States for 30 years. ${ }^{2}$ Currently, about $98 \%$ of the medical schools in the United States use some form of medical oath.

A remarkable development can be seen in how the classic Hippocratic oath is being displaced by other medical oaths and covenants, presumably because the classic oath ignores relevant ethical issues. Another custom of note is found in the Province of Quebec. Here, swearing a medical oath takes on political shadings as it is a prerequisite for obtaining a licence to practise.

In 1989 I surveyed the use of medical oaths at 126 medical schools in the United States; 119 replied. They reported the use of the oath of Geneva (33), the classic Hippocratic oath (three), a modified Hippocratic oath (67), the prayer of Maimonides (four), a convenant (one), other oaths (eight), an unknown oath (one), and no oath (two). Some used a combination of oaths and prayer.

Loudon or some other concerned physician should perhaps write to the medical schools to ascertain the present status of medical oaths in the United Kingdom. The answers may be surprising in view of the shared belief that medical practice is at heart a moral undertaking.

RALPH CRAWSHAW

Portland, OR 97210,

Clinical professor

Portland
USA

1 Loudon I. The Hippocratic oath. BMF 1994;309:414. (6 August.) 2 Crawshaw R. Contemporary use of medical oaths. $f$ Chronic Dis 1970;23:144-50.

\section{Is not administered in the strictly legal sense}

EDITOR,-Irvine Loudon may well be rightin the strictly legal sense-to conclude that the Hippocratic oath has never been administered in any medical school.' Nevertheless, for more than a century medical graduates of Aberdeen University have subscribed to something that in principle is not too far removed from it: "I solemnly declare that as a graduate in medicine of the University of Aberdeen, I will exercise my profession to the best of my knowledge and ability, for the good of all persons whose health may be placed in my care, and for the public weal; that I will hold in due regard the honourable traditions and obligations of the medical profession, and will do nothing inconsistent therewith; and that I will be loyal to the University, and endeavour to promote its welfare and maintain its reputation." As a sometime medical dean and promoter of graduates at Aberdeen one of us (THP) can vouch for the deep impression that its administration by the chancellor makes during the medical graduation ceremony.

The history of this declaration is complex. In essence, it was introduced in 1888 by the medical faculty in response to the discontinuation of the graduation oath hitherto taken by students in all faculties. ${ }^{2}$ The university had done this because the
We prefer short letters that relate to a recently published article and we are unlikely to publish letters longer than 400 words and containing over five references. Letters may be shortened. Your letters should be typed with double spacing and include a word count. All authors need to sign the letter and provide one current appointment and address. We encourage you to declare any conflict of interest. Please enclose a stamped addressed envelope if you require an acknowledgment.

centuries old oath contained religious sentiments to which a qualified candidate for the medical degree had been unable to subscribe on grounds of conscience, thereby preventing him from obtaining his degree.

TH PENNINGTON Professor of bacteriology CI PENNINGTON Medical historian
M

University of Aberdeen Aberdeen AB9 2ZD

1 Loudon I. The Hippocratic oath. BMf 1994;309:414. (6 August.) 2 Aberdeen University Court. Minutes of a meeting held on 21 May 1888. Aberdeen: University of Aberdeen, 1888.

\section{Origin is misunderstood}

EDrToR,-Irvine Loudon says that he does not know of any institution that administers the Hippocratic oath to doctors on graduation. ${ }^{1}$ Is such an expectation in fact based on a misunderstanding of the origin of the oath?

The healers in Cos (like elsewhere in the Greek world in the fifth and fourth centuries BC) were Asclepiads and as such belonged to a guild (koinon). Membership of the koinon was by descent from father to son. The only other means of entry to the guild was by marriage or adoption into an Asclepiad family. Hippocrates's grandfather and father were guild members before him, as were his two sons and his son in law after him. These physicians (iatroi) were in fact itinerant craftsmen who carried their skill from city to city, establishing in each a surgery. Nurses and assistants in these surgeries were bound by agreement-that is, the oath. This was a private contract between master and assistant and laid down a code of practice that society expected. Systematic instruction of medical students came later and probably not until after the founding of the medical school in Alexandria in the third century BC.

This concept of the origin of the oath as a contract betwen the physician and his non-medically qualified assistants explains the promise not to perform lithotomy. There is of course no single correct version of the oath. The oldest version we have is in the 10th century AD Urbinas text in the Vatican library, and this differs from subsequent versions that were "modified" in accordance with religious and other needs.

HERBERT REISS

Hariton,

Cambridge CB3 7ET

1 Loudon I. The Hippocratic oath. BMF 1994;309:414. (6 August.)

\section{Author's reply}

EDIToR,-From the numerous letters sent to me at home, as well as to the $B M F$, it is clear that my letter of 6 August was magnificently wrong. Oath taking is no myth: it is alive and well in a large number of medical schools, as shown in the editorial table. Because the origin and evolution of the Hippocratic oath is complex, ${ }^{1}$ it is not surprising that a wide variety of oaths and methods of administration exists today. Sometimes it is no more than a process of handing medical graduates (in the broad sense of the term) a copy of an oath which they may or may not be required to sign. A signed oath seems to be routine in French medical schools. In the Netherlands medical graduates are required either to take an oath or to "promise to do one's best," but it is compulsory either to swear or to promise (H Marland, personal communication). In many schools, however, a formal ceremony in which an oath is read out is either traditional or has been recently introduced or reintroduced-as, for example, at Johns Hopkins in Baltimore, where controversial parts of the oath such as swearing not to do abortions are "now smoothed over or omitted" (S Abram, personal communication).

What is surprising is the lack of general awareness on the extent of oath taking. Most graduates of non-oath taking medical schools will, I suspect, be unaware of the situation revealed by this correspondence. Although there is evidence, mostly anecdotal, that the content of the oath is soon forgotten, it is clear that medical schools that hold a formal oath taking ceremony set great store on the procedure and believe that it can affect subsequent ethical behaviour. Does this mean that the graduates of Oxford, Cambridge, and St Thomas's and Guy's display a lower standard of ethical behaviour than, for instance, graduates of Edinburgh, Cardiff, Leeds, and St George's Hospital? It is an entertaining thought. And it might be a suitable subject for a survey by experts in medical ethics, were it not for the probability that attempting to design a survey which produced a reliable measure of ethical behaviour, and also allowed for confounding factors, would defeat the project at its outset.

IRVINE LOUDON Medical historian

Wantage,

Oxfordshire OX12 9EH

1 Baker R. The history of medical ethics. In: Bynum WF, Porter $\mathrm{R}$, eds. Companion encyclopaedia of the history of medicine. Vol 2. London: Routledge: 852-87.

**We also received letters from the following correspondents who took the oath or were aware of its being administered in:

Bowman Gray School of Medicine, WinstonSalem, North Carolina, USA (Eben Alexander)

Edinburgh University (JJ C Cormack)

Erasmus University, Rotterdam, the Netherlands (Piet Bakx)

Glasgow University (A C Scott)

Karachi University (Shehnaz Somjee)

Leeds University (M D Speake)

Leiden, the Netherlands (Johanna C Wiersum)

Liverpool University (David John Brooks)

Marseilles University (S Sungum-Paliwal)

Queen's University of Belfast (W G M Bell)

Rome Medical School (Maria Stanowski)

Royal College of Surgeons in Ireland (John D C Bennett) 